\title{
Moninaisuus työelämässä ja johtamisessa $\mathbf{y}$ - erityisherkät persoonat työssä
}

\author{
Seija Ollila \& Anne Kujala
}

\section{ABSTRACT \\ Diversity in working life and leadership \\ - High sensitive individuals at work}

Labor productivity and well-being are prerequisites for working life. The prerequisite for productivity is to find work meaningful, which has a direct impact on well-being at work. Meaningfulness is linked to the possibility and willingness to organize work and act in a way that suits you. Taking into account different personalities and utilizing know-how supports the experience of individual meaningfulness and creativity in the organization. Personal diversity, which is also understood as difference, is a scant consideration in organizations and management of work communities.

Empirically implemented qualitative research is centered on a highly sensitive personality. Research questions focused on how diversity-sensitive personality is reflected in working life, how individual work-related sensitivity should be taken into account at work and what kind of competence based management or leadership are needed? The survey was targeted at the members of the Finnish Association for High Sensitive Person's (HSP) Association $(\mathrm{N}=944)$ in the autumn 2018. The analysis was performed by data-driven content analysis and by using quantification of the data. The lack of understanding of high sensitivity and intuitive abilities, practices, and needs of a person with a particular sensitivity to work revealed key findings. A highly sensitive person as an employee and a leader acts with strong empathy and emotional intelligence. She or he is heavily burdened by a poor working atmosphere and lack of appreciation. The highly sensitive person needs a peaceful working environment and a acceptance of diversity. Training and knowledge about high sensitivity is needed in working life and management.

Keywords: Diversity, Working Life, Leadership, High Sensitive Person, Well-being at Work, Qualitative-quantitative Research

\section{JOHDANTO}

Tuottavuus ja tehokkuus ovat tämän päivän työelämän keskeisiä teemoja. Näiden teemojen sisäistämisen ohella edellytetään työntekijöiltä innovatiivisuutta ja aktiivisuutta entistä paremman työpanoksen antamiseen. Yksilöiden persoonalliset toimintatavat ovat monesti hyvin monitahoisia ja vaihtelevia, joten varsinkaan tehokkuuden määrittäminen ei ole kovin yksinkertaista persoonakohtaisesti. Joka tapauksessa työn tekemisen tulee olla mielekästä ja mielekkyyttä työhön saadaan sillä, että yksilö voi tehdä itseään kiinnostavaa työtä, hyödyntää vahvuuksiaan, tehdä työnsä hyvin ja saada arvostusta (Järvinen 2014). Koemme sitten olevamme introverttejä, ekstroverttejä, ambiverttejä tai erityisherkkiä, keskeistä on huomioida erilaisten persoonallisuuksien tietotaito, parhaat toimintatavat ja osaaminen.

Moninaisuus on työyhteisössä voimavara ja mahdollisuus luovuuden ilmentymään (Jabe 2017). Se rakentuu monenlaisesta persoonallisesta osaamisesta ja tietotaidosta, joka valitettavasti jää usein turhaan piiloon. Kaikki ihmiset ovat erilaisia toimijoita, he tekevät eri tavoin ja erilaisella intensiivisyydellä työtään. Tässä kohtaa voidaan puhua toimijuudesta, johon kytkeytyvät yksilön tahdon- ja toiminnanvapaus, tavoitteellisuus ja suunnitelmallisuus tietyssä ympäristössä (Kotiranta \& Virkki 2011, 114; Laulainen 2010,30). Johtajalla ja erityisesti lähijoh- 
tajalla on tärkeä rooli jokaisessa työyksikössä mahdollistaa erilaisuus ja erityisesti sen hyväksyminen (Colliander, Ruoppila \& Härkönen 2009.) Hyväksyminen edellyttääkin tietynlaista asennetta, joka ei näy johtajuudessa oman edun tavoitteluna, itsekkyytenä, itsensä korostamisena eikä omahyväisyytenä, vaan työyhteisön jäsenten arvostamisena ja kannustamisena (Copee \& Galloway 2014). Tällaisella asenteella johtaja mahdollistaa erilaisuuden, antaa tilaa yksilön osaamiselle, osallisuudelle ja vaikuttamiselle, mikä puolestaan vapauttaa luovuutta ja lisää mielekkyyden tunnetta työssä. Johtamisosaamisen kehittämisellä on oma tärkeä paikkansa muun kouluttautumisen ohella (Ollila 2013; McKee 2015). Moninaisuuden oivaltamisella johtaja kykenee todennäköisesti rakentamaan vahvempaa tuottavuutta ja hyvinvointia työyhteisöön alasta riippumatta.

Tämän tutkimusartikkelin keskeisenä tavoitteena on nostaa esiin empiirisen tutkimuksen keinoin erityisherkän eli sensitiivisen persoonallisuustyypin kokemuksia ja näkemyksiä työelämästä sekä siitä, miten erityisherkkyys ylipäätään huomioidaan organisaatioissa yksilökohtaisesti ja osataanko siihen liittyviä voimavaroja hyödyntää riittävästi. Lisäksi artikkelissa pyritään huomioimaan erityisherkän johtajan kokemuksellisuutta ja haasteita johtaessaan työyhteisöä. Tutkimuskysymykset ovat näin ollen: 1) Miten moninaisuuteen kytkeytyvä erityisherkkä persoonallisuus näkyy työelämässä, 2) Miten yksilön erityisherkkyys tulee huomioida työssä ja 3) Millaista osaamista johtamisessa tarvitaan?

Teema on tutkimuksellisesti aiheellinen siksi, koska sitä ei ole erityisesti työelämään ja johtamiseen liittyen tutkittu Suomessa. Muualla maailmassa erityisherkkyys yksilön ominaisuutena on ollut tutkimuskohteena kuitenkin jo 1990-luvulta asti. Tässä tutkimuksellisessa artikkelissa keskitytään erityisherkkyyteen liittyvien vahvuuksien ja toisaalta mahdollisten haittojen huomioon ottamiseen työelämässä. Näin ollen tutkimuskohteeksi on nostettu nimenomaan moninaisuuteen kytkeytyvä erityisherkkä persoonallisuus (ks. Gardenswartz \& Rowe 1998).

\section{MONINAISET PERSOONALLISUUDET TYÖSSÄ JA TYÖYHTEISÖSSÄ}

\section{Persoonien moninaisuutta vai erilaisuutta - mitä erityisherkkyys on?}

Työyhteisöissä toimii hyvin erilaisia persoonallisuuksia. Antti Eskola (1985) kytkee persoonallisuuden ihmisen toimintaan, joka näkyy ulospäin. Erilaisuus käsitteenä ohjaa ajatuksia usein enemmän negatiiviseen kuin positiiviseen suuntaan, vaikka kyse on enemmänkin moninaisuudesta. Yksilön persoonallisuus on uniikki kokonaisuus luonteenpiirteitä, jotka koostuvat geeniperimästä, mutta ovat myös opittuja (Hofstede \& Hofstede 2005). Käsite moninaisuus tuleekin ymmärtää rikkautena ja voimavarana työyhteisössä, jolloin se antaa positiivisen näkymän ja tunnelman asialle. Moninaisuus rakentuu kerrostumista, joita ovat organisaatioon liittyvät tekijät, ulkoiset ja sisäiset tekijät sekä keskeisimpänä yksilön persoonallisuus. Organisaatiotekijät koostuvat muun muassa työn sisällöstä, toiminnallisesta tasosta ja johtajuudesta. Ulkoisia ja sisäisiä tekijöitä ovat työkokemus, koulutus ja sisäänpäin tai ulospäin suuntautuneisuus eli sosiaaliset ominaisuudet. (Gardenswartz \& Rowe 1998; Colliander ym. 2009.)

Moninaisuuden tiedostaminen, tunnistaminen ja arvostaminen työelämässä ovat keskeisiä vahvasti asenteisiin liittyviä tekijöitä jokaisessa organisaatiossa, mutta erityisesti asiantuntijaorganisaatioissa. Sillä on kauaskantoinen vaikutus myös luovuuteen ja innovointiin työyhteisöissä. (Wiskari 2009; Tavares 2016; Akinci Vural \& Liedtke 2017.) Työympäristön kehittäminen näiden arvojen suuntaan tarkoittaa, että ollaan tarpeeksi joustavia kohtaamaan moninaisuuteen liittyvät tarpeet ja edut, joilla sitten mahdollistetaan motivoitumista ja palkitsevuutta työssä (Jamieson \& O`Mara 1991). Haasteena tässä on yksilöiden kunnioittaminen kokonaisina ihmisinä yhdenvertaisesti, ei vain roolinsa edustajina (Colliander ym. 2009, 33). Erilaisuus ärsyttää, mutta se myös kiehtoo ihmisiä. Ihmisillä on usein tarve tasapäistää yksilöitä sillä ajatuksella, että tasapuolisuus ja oikeudenmukaisuus parhaiten toteutuisivat yhteisöllisesti. Näitä keskeisiä arvoja tulisi kuitenkin tarkastella hieman monipuolisemmin ja laajemmin (ks. Ajanko 2019). 
Moninaisuudella tai yhtä hyvin erilaisuudella on monia ulottuvuuksia. Näistä ensisijaisen huomion saavat ne ulottuvuudet, jotka ovat heti näkyvissä tai kuultavissa sekä toisaalta ne piilossa olevat taustavaikuttajat, jotka yksilö tuo esiin tarpeen tullen. Nämä jälkimmäiset taustalla olevat tekijät ovat pysyviä eroja, kuten esimerkiksi syntyperä, kansallisuus, elämänkatsomus, arvot. Kaikille yhteisiä tekijöitä ovat esimerkiksi rakkaus, terveydelliset sekä persoonakohtaiset tekijät, kuten yksilön omat kokemukset ja persoonallisuus. (Gardenswartz \& Rowe 1998; Wiskari 2009.) Persoonallisuuden merkityksestä työelämässä puhumattakaan persoonallisuuksien johtamisesta ja johtajan oman persoonan merkityksestä tässä kontekstissa puhutaan liiankin niukasti. Erilaisuus voidaan määritellä yksilön ominaisuudeksi, kun taas moninaisuus tulee nähdä yhteisöllisenä vahvuutena. Työyhteisössä erilaisuus voidaan nähdä myös toimijuutena, eli yksilön toiminnassa on olennaista tietoisuus siitä, että on mahdollisuus tehdä omaan elämään liittyviä päätöksiä ja toteuttaa niitä (Emirbauer \& Mische 1998, 970-973.) Näin aktiivinen toimija ottaa vastuuta ja haluaa kehittää itseään. (Laulainen 2010, 35-39.) Toimijuus näkyy haluna vaikuttaa sosiaalisiin suhteisiin ja toimia luovasti sekä aloitteellisesti (Fuchs 2001, 31.) Jokaisen työyhteisön jäsenen ainutlaatuisuus ja paras tapa toimia on toisaalta haaste johtamiselle (Ajanko 2019).

Tutkimuskohteena moninaisuuteen kytkeytyvä erityisherkkyys on varsin tuntematon ja kiistanalainenkin käsite, vaikka Sylvi-Sanni Manninen (Honkavaara 1914-2009) on tutkinut omassa väitöskirjassaan aihetta psykologian alalla jo 1950-luvulla ja kirjoittanut aiheesta julkaisuja (ks. Honkavaara 1958; Manninen 1999) sekä myöhemmin amerikkalainen Elaine Aron on perehtynyt samaan teemaan (ks. Aron \& Aron 1997). Tutkimusten mukaan ihmisistä noin 20 25 prosenttia on erityisherkkiä persoonallisuudeltaan (Aron 1997).

Aron \& Aronin (1997) mukaan erityisherkkä persoona on hyvin sensitiivinen ja intuitioherkkä. Hän käsittelee asioita syvällisesti pohtien ja hyvin tunnepitoisesti. Erityisherkkä persoona havainnoi tarkasti ympäristöään, huomaa pienetkin vivahteet, jotka muilta jäävät helposti huomaamatta sekä aistii herkästi ympärillään vallitsevan ilmapiirin. Rikas sisäinen maailma, voimakkaat tunteet ja aistimukset ohjaavat toimintaa työssäkin (Stefan Lindsay 2017). Liialliset ihmiskontaktit, häly ja kiire uuvuttavat, mutta samalla voimakas myötätuntoisuus ja empatiakyky ovat keskeisiä sekä positiivisia että negatiivisia ominaisuuksia. Negatiivista on se, että erityisherkkä yksilö helposti ylikuormittuu työtovereiden tunnetilojen aistimisesta ja työyhteisön huonosta ilmapiiristä. (Smolewska, McCabe \& Woody 2006; Jonkman 2015, 67-69; Löhken 2016, 218-221.) Erityisherkkyys (HSP= high sensitivity person) on Elaine Aronin mukaan persoonallisuuden ja hermojärjestelmän synnynnäinen ominaisuus. Hän nostaa esiin erityisherkille tyypillisen aistiyliherkkyyden (SPS= Sensory Processing Sensitivity), jota esiintyy arviolta 15-20 prosentilla ihmisistä (Jagiellowicz, Aron \& Aron 2016; Aron 2017). SPS lisää stressiin liittyvien ongelmien riskiä negatiivisissa työympäristöissä, mutta viestittää samalla niistä tarpeista, jotka ovat ilmeisiä erityisherkkien ja muidenkin ihmisten tukemisessa (Greven ym. 2019). Aistiyliherkkyys ei ole kuitenkaan mikään neurologiseen tai fysiologiseen sairauteen liittyvä tekijä, vaan se on yhteydessä ihmisten erilaiseen käyttäytymiseen ja kokemuksiin elintärkeiden tunteiden alueella (Jagiellowicz ym. 2016). Lähtökohtaisesti voidaan ajatella, että jokainen erityisherkkäkin on erilainen.

Yleisesti persoonallisuudet jaetaan karkeasti pääasiassa introvertteihin ja ekstrovertteihin, mutta puhutaan myös ambiverteista yksilöistä. Nämä persoonallisuudet mukaan lukien erityisherkkyys perustuvat ihmisen kokemuksellisuuteen. Seuraavaan taulukkoon 1 on poimittu eri lähteitä käyttäen näiden neljän eri persoonallisuuden keskeisiä ominaisuuksia, jotka heijastavat yksilöiden eroavaisuuksia ja yhtä hyvin yhtäläisyyksiä.

Aiempien vuosikymmenten yhteiskunnallinen normi suosi introversiota. Viimeisen viidenkymmenen vuoden aikana ihanteeksi on noussut ekstroverttikäytös. (Jonkman 2015.) Ekstrovertti persoonallisuus loistaa spontaanisuudellaan, ulospäin suuntautuneisuudellaan ja esiintymishalukkuudellaan. Johtajana hän on hyvin dynaaminen, impulsiivinen ja osittain dominoiva liiallisella läsnäolollaan antamatta muille työyhteisön jäsenille riittävästi tilaa. Introvertti yksilö puolestaan pohdinnoillaan ja tarkkuudellaan saa aikaan hyviä ideoita ja ratkaisuja omana 
Taulukko 1. Eri persoonallisuuksien ominaisuuksien vertailua (Aron, Aron \& Jagiellowicz 2012; Santos 2015; Jonkman 2015; Löhken 2016; Keltikangas-Järvinen 2019)

\begin{tabular}{|c|c|}
\hline $\begin{array}{l}\text { Introvertti } \\
\text { - Ei samaistu ryhmiin, omat mielipiteet ja } \\
\text { näkemykset itsenäisesti, pohdiskeleva } \\
\text { - Etsii hiljaisuutta, ei pitkästy yhtä helposti, on } \\
\text { harkitsevainen ja visualisoiva, tekee mieluummin } \\
\text { kuin puhuu, pidetään usein jähmeänä ja } \\
\text { tunteettomana } \\
\text { - Luova ongelmaratkaisukyky, pystyy ratkaisemaan } \\
\text { täysin uudenlaisia ongelmia, on tarkka } \\
\text { yksityiskohdissa }\end{array}$ & $\begin{array}{l}\text { Ambivertti } \\
\text { - } \quad \text { Voi työskennellä yksin ja ryhmässä } \\
\text { - Sosiaaliset tilanteet eivät uuvuta, paitsi, jos } \\
\text { venähtävät liian pitkiksi } \\
\text { - Hetkittäinen huomion keskipisteenä oleminen on } \\
\text { mukavaa } \\
\text { - Omiin ajatuksiin uppoutuminen, mutta myös } \\
\text { - } \quad \text { Omanusteleminen ihmisten kanssa luontevaa } \\
\text { puuduttaa }\end{array}$ \\
\hline $\begin{array}{l}\text { Ekstrovertti } \\
\text { - Viihtyy sosiaalisissa tilanteissa, hakee toimintaa ja } \\
\text { - Spontaaniutta ympärilleen } \\
\text { - Saa energiaa puheesta ja ympäristön } \\
\text { aktiivisuudesta, haastaa ja aktivoi yleisöään } \\
\text { sosiaalisesti lavasäteilyllään, panostaa enemmän } \\
\text { esiintymiseen kuin sisältöön } \\
\text { - } \quad \text { Ajattelee nopeasti ja pintapuolisesti, pystyy } \\
\text { tekemään nopeita ja rutiininomaisia päätöksiä }\end{array}$ & $\begin{array}{l}\text { Erityisherkkä } \\
\text { - } \quad \text { Reagoi erityisen herkästi ulkoisiin ja/tai sisäisiin } \\
\text { ärsykkeisiin } \\
\text { - } \quad \text { Tekee hienovaraisia havaintoja ja prosessoi } \\
\text { havaintojaan ja kokemuksiaan syvällisesti } \\
\text { - } \quad \text { Kuormittuu herkästi, koska poikkeuksellisen } \\
\text { herkkä fysiologinen stressijärjestelmä } \\
\text { - Tarkkaileva uusissa sosiaalisissa tilanteissa, } \\
\text { - } \quad \text { arempi kuin vähemmän herkkä enemmistö } \\
\text { samanaikaisesti, vastaanottavaisuus, } \\
\text { intuitioherkkyys }\end{array}$ \\
\hline
\end{tabular}

hiljaisena persoonanaan. Johtajana introvertti vetäytyy helposti liikaakin omiin oloihinsa, jolloin ehkä ristiriitojakin on vaikea ottaa käsittelyyn. Ambivertti yksilö tasapainottelee sujuvasti näiden edellä mainittujen persoonallisuustyyppien välimaastossa. (Löhken 2016, 265-268; (Keltikangas-Järvinen 2019, 191-207).)

Introvertteina ja ekstrovertteina itseään pitävät ovat toistensa vastakohtia lähestulkoon lähinnä sosiaalisen käyttäytymisensä perusteella, kun taas ambiverteiksi ja erityisherkiksi itsensä kokevien persoonissa löytyy piirteitä sekä introverttiudesta että ekstroverttiudesta. Vaikka Aronin alkuperäisten tutkimusten mukaan enemmistö erityisherkistä yksilöistä kuuluu introvertteihin, toteavat tutkijat Sobocko ja Zelenski (2015) heidän sijoittuvan temperamenteiltaan sekä introvertteihin että ekstrovertteihin. Jokaisella persoonallisuudella on omat vahvuutensa ja heikkoutensa. Keskeistä onkin huomioida jokaisen kohdalla se aineeton inhimillinen pääoma, jolla voidaan tuottavuutta ja työhyvinvointia vahvistaa työelämässä (Ajanko 2019, 9).

\section{Miten johtaa moninaisten persoonallisuuksien työyhteisöä?}

Moninaisuuden johtaminen tarkoittaa työyhteisössä erilaisuuksien havaitsemista, monipuolisen osaamisen ja vahvuuksien hyödyntämistä niin, että jokaisen yksilön motivaatio ja innostunut ote työhön säilyvät. Työyhteisöä tulee kehittää olemalla tarpeeksi joustavia niin, että erilaisuuden arvo voidaan nähdä ja todeta (Mannix \& Neale 2005; Colliander ym.2009; Satri 2019, 250-268). Johtajalta se edellyttää erilaisten persoonien toimintatapojen ymmärtämistä, kuuntelemisen taitoa, erilaisuuden arvostamista ja eettistä suhtautumista (ks. Jamieson \& O'Mara 1999; von Bergen, Soper \& Foster 2002; Wiskari 2009; Jabe 2017). Työyhteisön kehittämisessä tarvitaankin moninaista ja vastavuoroista vuorovaikutusta sekä havainnointitaitoja jokaisen jäsenen välillä johtaja mukaan lukien (Isotalus \& Rajalahti 2017; Ajanko 2019). Itseohjautuvuus on yksi keskeinen tekijä tarkasteltaessa mahdollisuutta järjestellä oma työ tavalla, jossa motivaatio ja innovatiivisuus kohoavat huippuunsa. Tämä tarkoittaa persoonallista ominaisuutta, 
jolloin yksilön toiminta on vahvasti omaehtoista ja hänellä on käsitys siitä, mitä osaamista hänellä on tai mitä hän tarvitsee lisää. (Martela \& Jarenko 2017, 12.) Samassa yhteydessä voidaan puhua myös itsejohtajuudesta (self-leadership), jossa yksilö kokee autonomisuuden kautta vaikuttamisen mahdollisuuksia omiin tapoihinsa tehdä työtä ja samalla vaikuttaa työyhteisönsä sekä koko organisaationsa valintoihin ja toimintaan. (ks. Manz 1992; Zigurs 2003.)

Moninaisuuden johtaminen työyhteisöissä edellyttää sensitiivisyyden lisäämistä kulttuurisesti ja vuorovaikutuksen kehittämistä ihmissuhteissa. Tämä tarkoittaa vahvasti sitä, että organisaatioiden kulttuuria ja johtamiskäytäntöjä tulee muuttaa ja päivittää. Toiminta edellyttää johtajalta syvää, introspektiivista reflektointia voidakseen paljastaa omat henkilökohtaiset asenteensa ja ennakkoluulonsa, jotka voivat toimia esteinä erilaisuuden hyväksymiselle ja sen hyödyntämiselle (ks. Ajanko 2019). Johtamisosaamisen kehittämisessä johtaja tarvitseekin organisaation ja työyhteisön jäsenten tukea kuin myös työnohjauksellista ja koulutuksellista vahvistamista. (Ollila 2006, 2008; Helms Mills, Dye \& Mills 2009, 155-168; Stefan Lindsay 2017.) Joycen $(2012,6)$ mukaan johtajan on oltava tilanteen tasalla ja tiedettävä, miten erilaisia ihmisiä johdetaan luottamuksellisuus huomioiden. Se edellyttää hyvää johtajan itsetuntemusta, yhteistyötä vahvistavaa ilmapiiriä ja ylipäätään mahdollistavaa johtamista. Ihmisten johtamisessa yksilön valintojen tekemisen salliminen työssä on mahdollistavaa silloin, kun se koskee myös työn tekemisen tavoitteita ja motiiveja (Perttula 2012, 136). Työyhteisön ja johdon tuki ovat keskeisiä elementtejä yksilön toimijuuden tunnon kehittymiselle sosiaalisissa ympäristöissä. (Hitlin \& Elder 2007, 40-43.) Turhan autoritaarisesta ja narsistisia piirteitä omaavasta johtamisesta, jossa oman edun tavoittelu on keskeistä, tulee päästä eroon. Sellainen johtaminen on huonoa ja voi vahingoittaa koko työyhteisöä ja organisaatiota. (Ollila \& Kujala 2018.) Sen sijaan korkeassa asemassa olevat johtajat, jotka omaavat empatiaa itsekeskeisen johtajuustyylin sijaan, ovat ihmissuhdetaitoisia ja siksi hyviä johtajia (Schmid Mast, Jonas \& Hall 2009).

\section{TUTKIMUSASETELMA}

Tutkimus sai alkunsa tutkijoiden mielenkiinnosta työelämän moninaisia ilmiöitä kohtaan. Persoonallisuuksien rikkaus ja jokaisen yksilön osaamisen sekä tietotaidon huomioiminen ovat keskeisiä tekijöitä työn tuottavuutta ajatellen (Ollila 2013). Toimiva työyhteisö koostuu samalla hyvinvoivista ja luovista yksilöistä. Tutkimusasetelman keskiössä ovat erityisherkät persoonallisuudet työelämässä, joka ilmiönä asemoituu moninaisuuden käsitteen sisään (ks. Tavares 2016).

\section{Tutkimusaineiston kuvaus}

Tutkimus toteutettiin sähköistä e-lomaketta käyttäen kohdennetusti Suomen Erityisherkkien yhdistyksen jäsenille syksyllä 2018. Yhdistyksessä oli jäseniä tuolloin yhteensä 944. Levityskanavina käytettiin yhdistyksen kotisivuja ja sosiaalista mediaa. Yhdistys mainosti jäsenkirjeessään tutkimusta ja tutkijan yhdistykselle lähettämää blogikirjoitusta, josta löytyi linkki kyselyyn. Lomake sisälsi taustatietojen lisäksi yhdeksän strukturoitua avointa kysymystä, jotka analysoitiin aineistolähtöistä sisällönanalyysiä hyödyntäen. Nämä yhdeksän kysymystä olivat seuraavanlaiset: 1) Miten erityisherkkyys näkyy työpaikoilla, 2) mitä vahvuuksia ja osaamista sinulla on erityisherkkänä työntekijänä, 3) millaisia haittoja tai uhkia erityisherkkyydestä on työelämässä, 4) miten yksilön erityisherkkyyttä ja osaamista tulee työelämässä huomioida ja hyödyntää, 5) millä tavoin erityisherkkyyttä tulee työelämässä tukea, 6) miten erityisherkkyys tulee huomioida johtamisessa, 7) mitä osaamista ja tietotaitoa johtajalla tulee olla johtaessaan erityisherkkiä työntekijöitä, 8) millaista tukea erityisherkkänä johtajana kaipaisit sekä 9) mitä muuta haluat sanoa. Kysymysten aihepiiri kohdentui työelämään ja sen toteutumiseen moninaisuuteen kytkeytyvän persoonan, erityisherkän näkökulmasta.

Lomakkeen toimivuus testattiin kolmen erityisherkäksi itsensä kokevan henkilön avustuksella ja sitä muokattiin jonkin verran palautteen perusteella. Avoimista vastauksista muodostettiin myös jonkin verran määrällisiä lukuarvoja, lähinnä prosentteja, kvantifioimalla aineistoa. 
Tämä tapahtui lukemalla aineisto tarkasti ensin läpi ja merkitsemällä manuaalisesti samansisältöiset ilmaisut yhteen, jolloin voitiin saada tuloksiin hieman tilastollista näkyvyyttä. Tietenkin myös kyselyn perustietojen esittäminen edellytti tilastollista käsittelyä. (Tuomi \& Sarajärvi 2013). Kysely oli avoinna vastaajille syyskuun 2018 ajan. Tavoitteena oli koota tutkimuksen kohteena olevan erityisryhmän näkemyksiä, miten heidän vahvuuksiaan huomioidaan ja miten heidän osaamistaan työelämässä osataan johtaa tuottavasti unohtamatta hyvinvointia ja sitä, että johtajakin itse voi olla erityisherkkä. Kysely suunnattiin sekä perustyössä toimiville että johtamistyötä tekeville tai tehneille henkilöille, jolloin mahdollisuutena oli saada monipuolisempaa tietoa tutkittavasta asiasta. Aineistonkeruu toteutettiin luottamuksellisuuden varmistamiseksi anonyymisti ja saatu jäi tutkijoiden käyttöön.

Vastauksia kyselyyn saatiin yhteensä 155 $(\mathrm{N}=944)$, jolloin vastausprosentiksi tuli $15 \%$. Naisia vastaajista oli 141 ja miehiä 14 . Koulutustaso rakentui enimmäkseen skaalasta ammattikoulutuksesta ylempään korkeakoulutukseen, mutta myös alimman asteen ja toisaalta ylimmän asteen koulutuksen hankkineita oli vastaajissa. Ikäjakaumassa oli pääasiassa 50 \% 31-49 ja 34 \% 50-65 -vuotiaita, mutta myös nuorempia ja vanhempia vastaajia oli mukana. Vastaajista $27 \%(n=53)$ edusti vahvimmin sosiaali- ja terveysalaa ja koulutusalaa $11 \%(\mathrm{n}=16)$, mutta $13 \%(n=20)$ vastaajista oli kokemusta useammalta alalta. Joka tapauksessa lähes kaikki ammattialat ja moninaiset ammattinimikkeet olivat edustettuina mukaan lukien eläkeläiset, sairaseläkeläiset, työttömät ja opiskelijat.

Avoimet kysymykset tuottivat aineistoa yhteensä 91 sivua (fontti Times New Roman 12, riviväli yksi). Kaikkiin kysymyksiin eivät vastaajat olleet vastanneet yhtä laajasti, mutta silti hyvin monipuolisesti. Sisällönanalyysiä hyödyntämällä pyrittiin löytämään aineiston sisältämiä merkityksiä tutkittavasta teemasta (vrt. Eskola \& Suoranta 2003; Tuomi \& Sarajärvi 2013). Aineisto luettiin useampaan kertaan läpi, pelkistettiin saatu informaatio kysymyksittäin ja ryhmiteltiin kyselyn aihepiirien mukaisesti (ks. Alasuutari 1999). Tästä sisällönanalyysiprosessista seuraava lyhyt esimerkki:
Alaluokka: kokemus johtajana, erityisherkkä persoonallisuus

Yläluokka: kuuntelemisen taito, vahva empatiakyky, tunneäly

Pääluokka: lisäarvo ihmisten johtamisessa.

Kokonaisuuksia tarkastelemalla aineistosta tehtiin lopuksi tulkintoja ja tulkintojen tueksi poimittiin mahdollisimman kuvaavia vastaajien siteerauksia.

\section{TUTKIMUSTULOKSET}

\section{Miten moninaisuuteen kytkeytyvä persoonallisuus näkyy työelämässä?}

Tutkimuksen aluksi pyrittiin saamaan erityisherkkien yksilöiden näkemyksiä siitä, miten erityisherkkyys näkyy ja miten se huomioidaan ylipäätään työelämässä. Toisena tavoitteena oli tutkia, millaisia vahvuuksia ja osaamista erityisherkkyys antaa yksilölle ja millaista haittaa tai mitä uhkia henkilö kokee työelämässä. Lisäksi tärkeä tavoite oli saada näkemyksiä siitä, miten yksilön erityisherkkyyttä ja osaamista tulee työelämässä huomioida ja hyödyntää niin, että sitä ei menetettäisi. Muutamat prosenttiluvut joidenkin näkemysten kohdalla ovat manuaalisesti laskettuja huomioita aineistosta $(\mathrm{N}=155)$. Tutkimustulokset perustuvat täysin vastaajien omiin työelämän kokemuksiin erityisherkkyydestä, koska he kokevat olevansa erityisherkkiä persoonia. Introverttiutta, ekstroverttiutta tai ambiverttiutta ei näissä tuloksissa ole olennaista erityisesti korostaa, vain huomioida niiden olemassaolo.

Ensimmäiseen kysymykseen, miten erityisherkkyys näkyy työpaikoilla, vastaajat olivat sitä mieltä, että erityisherkkyyttä ei työelämässä huomioida mitenkään, se on varsin tuntematon käsite tai sen ei anneta näkyä. Monesti "tuntuu siltä, ettei sitä haluta edes tunnistaa" ja "moni ajattelee, että erityisherkkyys on vain höpötystä ja herkän oma keksintö". Toisaalta omaa erityisherkkyyttään yksilö ei rohkene aina edes tuoda esiin, koska pelkää muiden pitävän häntä outona ja poikkeavana. On parasta yrittää vain sulautua joukkoon. Näkyväksi tuleminen riippuu täysin organisaation kulttuurista, johtamisesta ja työn- 
tekijöistä, joiden toiminta ja asenteet perustuvat sallivuudelle kohdata persoonallista erilaisuutta (ks. Helms Mills ym. 2009; Ajanko). Ei pelkästään sallivuus ole keskeistä, vaan erityisherkkyyden tuomien mahdollisuuksien hyödyntäminen ja haasteiden huomioon ottaminen. Hyötynäkökulmia on todella paljon, mutta samalla haasteiksi nousevat pääasiassa työolosuhteet. (vrt. Colliander ym. 2009; Wiskari 2009.)

Mitä vahvuuksia ja osaamista erityisherkillä sitten on ja miten heidän osaamistaan tulee työelämässä huomioida ja hyödyntää optimaalisesti? Vastausten perusteella erityisherkät yksilöt tekevät työtään erittäin tunnollisesti. He ovat tarkkoja, luotettavia, toimivat itsenäisesti ja keskittyvät vahvasti meneillään oleviin työtehtäviinsä. Tarkkuus pohjautuu vahvaan huomiointikykyyn tutkia ja pohtia asioita monelta kantilta, nähdä ja löytää pienet sävyerot ja vivahteet ajoissa. Kokonaisuuksien hahmottaminen ja rakentaminen on helppoa, koska erityisherkällä on "syvällinen kyky ymmärtää asioita ja integroida ne kokonaisuuksiin". Luovuus on keskeinen elementti erityisherkkyydessä. Vastanneista moni kertoi olevansa hyvin luova sekä työssään että henkilökohtaisessa elämässään, mikä näkyy taiteellisena osaamisena, hyvänä esiintymiskykynä tai lahjakkuutena sekä halukkuutena kehittää työtä ja omaa osaamistaan (ks. Tavares 2016). "Uskon herkkyyden näkyvän luovuutena (uusien ideoiden keksiminen, ongelmanratkaisu), empaattisuutena ja kykynä havaita epäkohtia ja kehitystarpeita". Lisäksi he olivat sitä mieltä, että luovuus perustuu asioiden ennakoimiseen, vahvaan intuitioon ja kykyyn havainnoida tilanteita, ympäristöä, muita ihmisiä sekä heidän tunnetilojaan. Vastanneista erityisherkistä yksilöistä noin viidennes onkin erittäin empatiaherkkiä ja heillä on kyky asettua toisen asemaan sekä taito kuunnella. (ks. myös Aron 2017). He ovat helposti lähestyttäviä ja yhteishengen luojia, jolloin hyödyntävät omaa tunneälyään ihmisten kanssa toimiessaan. Suurin osa vastaajista tämän tutkimuksen mukaan työskenteleekin sosiaali- ja terveysalalla tai koulutusalalla sekä ylipäätään asiakaspalveluissa, joissa tunneälyllä ja empatiakyvyllä on keskeinen merkitys. Seuraava vastaus kuvaa varsin hyvin erityisherkkää persoonallisuutta: "Erityisherkkyys tekee minusta parhaimmassa tapauksessa erittäin fiksun, tehokkaan ja monipuolisen työntekijän. Teen sekä oman työni erittäin hyvin, että huomioin myös muut ja tuen heitä työtehtävissään”.

Erityisherkkä persoonallisuus voi lukeutua sekä ekstrovertteihin että introvertteihin, kuten ambiverttikin (ks. Gerlach ym. 2018), vaikka usein vaikutelma hänestä painottuu enemmän introverttiuteen, mitä kuvaa seuraavan vastaajan siteeraus: "Erityisherkkä pohdiskelee ja on yleensä hiljaisempi kuin muut, mutta saattaa silti antaa erinomaisia ideoita pohdittuaan itsekseen". Vastaajien mukaan erityisherkällä on tarve saada rauhallinen työympäristö ja tila sekä työrauha. Melu, hälinä, informaatiotulva ja huono, kireä työilmapiiri aiheuttavat kuormittavuutta työssä. Avokonttori koetaan täysin sopimattomaksi työympäristöksi juuri oman rauhallisen tilanpuutteen vuoksi seuraavan kommentin mukaan: "avokonttori on ajatuksenakin monelle meistä varmasti kammottava". Kyselyyn vastanneista $22 \%(n=33)$ kuvaa omaa näkemystään erityisherkkyydestä juuri ärsykeherkkyytenä. (vrt. Greven ym. 2019.)

\section{Miten yksilön erityisherkkyys tulee huomioida työssä?}

Erityisherkkiin kohdistuva suurin uhka ja haitta työelämässä on kuormittuneisuus (vrt. Stefan Lindsay 2017). Vastaajista yli puolet kokee kuormittuvansa herkästi. Heistä tähän liittyy ajatus loppuun palamisesta, johon kuuluvat erityisesti myötätuntouupumus, kokemus muiden varjoon jäämisestä ja joutumisesta väärinymmärretyksi, ahdistava työilmapiiri sekä työpaikkakiusaamisen kohteeksi joutuminen. Myötätuntouupumukseen kuuluu vahva empatiaherkkyys, jolloin henkilö pystyy aistimaan ihmisten sanattomiakin viestejä ja toiveita, on aktiivinen ja herkkä kuuntelemaan toisten murheita sekä samalla tunneherkkänä ja intuitiivisena elää täysillä työyhteisön tilanteissa ja tunnelmissa (ks. Aron \& Aron 1997). Huono, kireä työilmapiiri ja väljyyden sekä keskittymisrauhan puute ovat uhkana työhyvinvoinnille. Ihmisten väliset konfliktit ja ristiriidat koetaan uhkaavina, kun ilmapiiriongelmat havaitaan jo intuitiivisella tarkkuudella (vrt. Smolewska ym. 2006). "Erityisherkkä kuormittuu tai ylivirittyy helposti. Hän ehkä saattaa ottaa liikaa vastuuta muistakin ihmisistä ja heidän hyvinvoinnistaan, tekee helposti muidenkin puolesta. Ihmissuhdetyössä voi 
olla vaikea irtautua muiden tunteista". Ristiriidat tuleekin käsitellä mahdollisimman varhaisessa vaiheessa ja ongelmista keskusteleminen avoimesti on ehdottoman tärkeää (ks. Smolewska ym. 2006; Löhken 2016). Erityisherkkä persoonallisuus tarvitsee sekä työyhteisön muiden jäsenten että johtajien ja esimiesten tukea oman osaamisensa ja vahvuuksiensa toteuttamiseksi optimaalisesti.

\section{Millaista osaamista erityisherkkien johtamisessa tarvitaan?}

Erilaisuuden varaan rakentaminen edellyttää johtajalta reflektointikykyä. On tutkittava omaa johtamistaan ja kuunneltava toisia sekä arvostettava erilaisia mielipiteitä (ks. Jamieson \& O'Mara 1991; Jabe 2017). Kyseenalaistaminen ei ole pahasta. Vuorovaikutus on keskeistä (vrt. Ajanko 2019). Työyhteisöt välttävät helposti ongelmien käsittelyä ja keskusteleminen niistä on kiusallista etenkin, jos ei ole menetelmiä kohdata erilaisuutta. Erään vastaajan mukaan "Työnantajan täytyisi tunnistaa erilaiset ihmistyypit ja kunnioittaa jokaisen erityispiirteitä", eli antaa vapautta käyttää voimavaroja tavalla, joka yksilölle parhaiten sopii.

Miten erityisherkkyys tulee huomioida johtamisessa ja mitä osaamista johtajalla tulee olla? Vastaajat pitivät tärkeänä, että heitä kuunnellaan ja ymmärretään, hyväksytään erilaisuus ja huomioidaan yksilöllisyys työyhteisöissä. "Erilaisuus tulee huomioida eikä yrittää saada kaikkia samaan muottiin" ja "paras esimies on aidosti kuunteleva ja joustoihin kykenevä". Vastaajien mielestä johtamisessa tarvitaan empatiaa ja tunneälyä sekä vahvaa ihmistuntemusta. "Pitää olla kiinnostusta tunnistaa, hyväksyä ja hyödyntää erilaiset persoonallisuuden piirteet", joita vain hyvällä ihmistuntemuksella ja ymmärryksellä kykenee huomioimaan (ks. Joyce 2012). Toisaalta jokaisella yksilöllä työyhteisössä on omat tarpeet ja haasteet, ei erityisherkän tarvitse olla mitenkään erityisasemassa. Viidesosa vastaajista kaipasi ennen kaikkea työrauhaa. Johtajan tulee toki olla ymmärtäväinen kaikkien haasteita kohtaan. Hyvällä ilmapiirillä, sen luomisella ja säilyttämisellä on keskeinen rooli työntekijöiden hyvinvoinnissa (ks. Jabe 2017).

Hyvin autoritaarista ja narsistista johtajuutta ilmenee valitettavan paljon tämän päivän orga- nisaatioissa, vaikka niiden kielteiset vaikutukset tiedostetaan ihmisten toimintaan työssä (ks. Ollila \& Kujala 2018). Vastaajista $33 \%(n=49)$ oli sitä mieltä, että tarvitaan enemmän tietoa erilaisten ihmisten johtamisesta ja erityisherkkyydestä, mutta erityisesti johtamiskoulutuksissa teema olisi tarpeellista ottaa esiin. Seuraava kommentti kuvaa hyvin niitä tarpeita ja odotuksia, joita monissa muissakin vastauksissa nousi esiin. "Toivoisin koulutusta esimiehille ja johtajille tässä asiassa, muuten erityisherkkyyttä ei voi onnistuneesti tukea työelämässä. Työilmapiiriin pitää kiinnittää erityistä huomiota ja johtaminen by perkele ei yksinkertaisesti toimi, vaan saa aikaan vain tuhoa". Tiedon jakamisella siitä, millaisia taitoja ja lahjakkuuksia erityisherkkä voi tarjota työyhteisöön, on hän sitten introvertti tai ekstrovertti persoona, on suuri merkitys. "Tarvitaan introverttejä ja ekstroverttejä, suurpiirteisiä ja pikkuseikkoihin takertuvia, esiintyjiä ja tarkkailijoita, hassuttelijoita ja tosikkoja sekä monenlaisia muita tyyppejä", kuten eräs vastaaja asian myös ilmaisi. Tähän perustuen johtajan tulee kyetä hyväksymään ihmisten erilaisuutta ja herkkyyttä sekä oppia kunnioittamaan henkilöitä sellaisenaan (vrt. Wiskari 2009; Ajanko 2019).

Entä, jos johtaja itse on erityisherkkä? Tutkimuksen taustatietojen mukaan aineistosta yhteensä $28,9 \%(n=43)$ toimi tai oli toiminut johtamistyössä. Johtamistehtävät eivät sinänsä olleet kovin houkuttelevia tämän tutkimuksen mukaan lähinnä työn vaativuuden ja kuormittavuuden vuoksi. Ennemminkin tehtäviä pyrittiin välttämään, jos se oli mahdollista. Vastaajien mukaan johtajana erityisherkkä yksilö muiden erityisherkkien tapaan on empatiakykyinen ja hänellä on tunneälyä. Hän osaa intensiivisesti kuunnella ja hän aistii herkästi muiden työyhteisön jäsenten tunnetiloja ja työyhteisön ilmapiirin eri sävyjä. Kuuntelemisen taito auttaa häntä ymmärtämään yksilöitä ja tilanteita työyhteisössä. Luovuus ja kehittämisinnokkuus ovat luontaisia ominaisuuksia. Vivahteiden huomiointi ja halu viedä asioita eteenpäin tietynlaisella järjestelmällisyydellä ja tunnollisuudella on vahvuus, mutta samalla uuvuttava tekijä. (vrt. Aron 2017; Greven 2019.) Tunnollisuus voi ollakin jonkinlaista vahvaa kiltteyttä ja pedanttisuutta, joka vie voimavaroja. Vahva empatiakyky puolestaan saattaa johtaa hyväksikäyt- 
Taulukko 2. Moninaisuuteen kytkeytyvä erityisherkkyys työssä ja johtamisessa

\begin{tabular}{|c|c|c|}
\hline $\begin{array}{l}\text { Erityisherkkä } \\
\text { persoona työssä }\end{array}$ & Tunnistettavuus & $\begin{array}{l}\text { Tiedostaminen ja huomioiminen } \\
\text { työelämässä }\end{array}$ \\
\hline Näkyvyys & $\begin{array}{l}\text { Ei tunnisteta, ei huomioida tai ei uskalleta tuoda } \\
\text { esiin. }\end{array}$ & $\begin{array}{l}\text { Tiedon lisääminen monipuolisesti } \\
\text { erityisherkkyydestä. } \\
\text { Moninaisuuteen kytkeytyvän } \\
\text { persoonallisuuden ymmärtäminen, } \\
\text { hyväksyminen ja näkyväksi } \\
\text { tekeminen. }\end{array}$ \\
\hline $\begin{array}{l}\text { Vahvuudet ja } \\
\text { tietotaito }\end{array}$ & $\begin{array}{l}\text { Tunnollisuus, luovuus, huomiointikyvyn tarkkuus, } \\
\text { intuitioherkkyys, kehittämishalukkuus ja vahva } \\
\text { empatiakyky. }\end{array}$ & $\begin{array}{l}\text { Erityisherkän luovuus ja tunneäly } \\
\text { työyhteisön voimavaraksi. } \\
\text { Vaikutusmahdollisuuksien lisääminen } \\
\text { oman työn toteuttamiseen. }\end{array}$ \\
\hline Haitat ja uhat & $\begin{array}{l}\text { Melu, rauhaton työympäristö ja } \\
\text { informaatiotulva kuormittavat, ärsykeherkkyys. } \\
\text { Muiden tunnetilojen aistiminen aiheuttaa } \\
\text { myötätuntouupumusta. Intuitioherkkä kuormittuu } \\
\text { huonosta ilmapiiristä ja konflikteista. }\end{array}$ & $\begin{array}{l}\text { Työtilajärjestelyt sopiviksi erilaisille } \\
\text { yksilöille. } \\
\text { Ristiriitojen käsittely avoimesti } \\
\text { keskustellen mahdollisimman } \\
\text { varhaisessa vaiheessa. }\end{array}$ \\
\hline Johtaminen & $\begin{array}{l}\text { Ei tunnisteta riittävästi organisaatioissa } \\
\text { moninaisuuteen kytkeytyvää persoonallisuutta. } \\
\text { Arvostuksen puute } \\
\text { Suositaan ekstroverttiutta enemmän suhteessa } \\
\text { introverttiuteen. }\end{array}$ & $\begin{array}{l}\text { Kuunteleminen, ymmärtäminen ja } \\
\text { erilaisuuden hyväksyminen keskeistä, } \\
\text { työrauhan salliminen. } \\
\text { Empatiaa ja tunneälyä lisättävä. } \\
\text { Tiedon lisääminen } \\
\text { erityisherkkyydestä } \\
\text { johtamiskoulutuksella. }\end{array}$ \\
\hline $\begin{array}{l}\text { Erityisherkkä } \\
\text { johtaja }\end{array}$ & $\begin{array}{l}\text { Empatiakykyinen, aistii työyhteisön ilmapiirin eri } \\
\text { sävyjä. } \\
\text { Järjestelmällisyys vahva asioiden eteenpäin } \\
\text { viemisessä. }\end{array}$ & $\begin{array}{l}\text { Oman esimiehen ja työyhteisön tuki } \\
\text { keskeistä. } \\
\text { Tarvitsee vertaistukea ja } \\
\text { työnohjauksellista toimintaa. } \\
\text { Vahva empatiakyky antaa lisäarvoa } \\
\text { työyhteisön työhyvinvoinnin } \\
\text { säilyttämiseen. }\end{array}$ \\
\hline
\end{tabular}

töön tunnetasolla. Erityisherkkyytensä vuoksi johtaja kuormittuu herkästi ja varsinkin, jos hänellä on vastuuta paljon eikä hän saa riittävää arvostusta työssään. (vrt. von Bergen ym. 2002; Ajanko 2019). Vastanneista johtajista lähes jokainen piti erittäin keskeisenä oman esimiehen ja työyhteisön tukea palautteineen ja arvostuksen antamisineen. Lisäksi "kaipaan reflektointikumppania jostakusta jota kunnioitan, ja joka osaa"..."lojaalia työyhteisöä", mikä tarkoittaa, että erityisherkkä johtaja tarvitsee vertaistukea ja työnohjauksellista toimintaa työssään (ks. Hitlin \& Elder 2007; Ollila 2008; Stefan Lindsay 2017). Taulukossa 2 on tutkimusaineistosta tehdyt tulkinnat koottu yhteen mahdollisine kvantitatiivisine arvoineen.

Moninaisuuteen kytkeytyvän erityisherkkyyden näkyvyys, yksilöiden vahvuudet ja osaami- nen, persoonallisuuteen nivoutuvat haitat ja uhat sekä kokemukset johtamisesta ja itse johtajana toimimisesta työelämässä on tämän päivän organisaatioissa puutteellisesti tunnistettua. Erityisherkkyyden kuin myös muidenkin persoonallisuuksien tiedostaminen ja huomioiminen on ensiarvoista, kun kehitämme työyhteisöjämme ja organisaatioitamme hyväksymään erilaisuus moninaisuutena ja ymmärtämään sen välttämättömyys (vrt. Keltikangas-Järvinen 2019).

\section{JOHTOPÄÄTÖKSET}

Moninaisuuteen kytkeytyvä persoonallisuus on huomion arvoinen asia nykyaikana, jolloin työelämässä edellytetään vahvaa yksilön innovatiivista ja luovaa panostusta työn tekemisessä. 
Työvoiman riittävyys eri ammattialoilla on yleinen huolenaihe valtakunnallisesti, mutta huoli on myös ihmisten jaksamisesta ja työhyvinvoinnista ylipäätään, mikä kytkeytyy työn tekemisen mielekkyyteen, työoloihin ja erilaisten persoonallisuuksien tarpeisiin tehdä työtään ja tuoda osaamistaan esiin (vrt. Järvinen 2014). Nämä tekijät linkittyvät samalla yksilön toimintaan ja toimijuuteen työelämässä (vrt. Fuchs 2001). Moninaisuuteen kytkeytyvän persoonallisuuden ymmärtäminen ja hyödyntäminen lähtevät siitä, että tiedostetaan olemassa olevat tekijät, lisätään tietoa ja koulutetaan organisaatioiden esimiehiä ja johtajia. Persoonallisuuksina introvertit, ekstrovertit, ambivertit ja erityisherkät yksilöt tuovat varmasti omat erityiset kykynsä ja osaamisensa esiin työssä, kun heidän toimintatapansa huomioidaan ja hyväksytään (vrt. Ajanko 2019). Tämä tarkoittaa näin ollen oikeaa asennetta yksilön arvostamiseen ja kannustamiseen sekä tunneälyn lisäämistä. Johtamisessa autoritaarisuuden minimointi ja toisaalta empaattisuuden korostaminen ovat keskeisiä tekijöitä. Kun erilaisuutta kunnioitetaan ja se otetaan käyttöön, voidaan herkästi tukea työilmapiirin terveellisyyttä ja vahvistaa työn mielekkyyden kokemuksia sekä samalla ehkäistä työuupumusta (vrt. Stefan Lindsay 2017). Moninaisuuteen kytkeytyvä persoonallisuus tuleekin nähdä voimavarana ja luovuuden ilmentymänä.

Vaikka erityisherkkyyttä on tutkittu erityisesti psykologian alalla Amerikassa ja Suomessakin jossain määrin 1950-luvulla (ks. Honkavaara 1958; Manninen 1999), silti sen tiedostaminen erityisesti työelämässä ja johtamisessa on jäänyt hyvin vähäiseksi. Tutkimuksista huolimatta aihe on edelleenkin hyvin kiistanalainen (ks. mm. Aron \& Aron 1997; Aron 2017). Julkisuudessa aihetta on käsitelty yhä enenevässä määrin ja erilaisia persoonallisuuksia mittaavia menetelmiä on kehitelty niin introversion, ekstroversion kuin erityisherkkyydenkin määrittelyiksi. Tämän tutkimuksen lähtökohtana oli pääasiassa paneutua moninaisuuteen kytkeytyvään persoonallisuuteen juuri erityisherkkien ihmisten näkökulmasta käsin, nimenomaan työelämäkontekstissa.

Keskeisinä huomioina tutkimuksen mukaan nousi yleisesti vähäinen ymmärrys erityisherkkyydestä. Erityisherkkien johtamisessa tarvitaan vahvaa johtamisosaamista (ks. Ollila 2006).
Varsinkin työelämässä tällaista persoonaa voidaan pitää hyvin outona käyttäytyjänä tai erityisherkkä itse kokee olevansa erilainen, eikä rohkene tuoda edes omasta mielestään parhaita persoonallisuuden piirteitään työssä esiin. Tunnollisuus ja empatiakyky ovat vahvoja hyveitä, mutta ne myös kuormittavat yksilöä voimakkaasti (ks. Smolewska ym. 2006; Löhken 2016; Aron 2017; Satri 2019). Erityisherkkä persoona toivoo ennen kaikkea työrauhaa, mahdollisuutta vaikuttaa oman työnsä toteuttamiseen (vrt. Zigurs 2003) ja hänelle sopivaa rauhallista työtilaa (ei avokonttoria) luovuutta edellyttävässä tehtävässä. Koska luovuus on hyvin vahva piirre, olisi esimiesten ja johtajien annettava tilaa seikkaperäiselle ja intensiiviselle kehittämistyölle, jota idearikkaus pohdiskeluna tuo esiin. Vaikka erityisherkät persoonat eivät ehkä mielellään hakeudu johtamistehtäviin, ovat he kuitenkin potentiaalisia ihmisjohtajia empaattisuutensa ja kuuntelemisen taitonsa perusteella (ks. Schmid Mast ym. 2009).

Tämä tutkimus toteutettiin sähköisen kyselylomakkeen avulla, jossa perustietojen lisäksi oli ainoastaan avoimia kysymyksiä. Avointen kysymysten sijaan tutkimuksessa olisi voitu käyttää erilaisia väittämiä aiheeseen liittyen ja toteuttaa aineiston analyysi kvantitatiivisin menetelmin kokonaisuudessaan. Vastauskatoa saattoivat selittää avoimet kysymykset ja se, etteivät kaikki yhdistyksen jäsenet käy aktiivisesti yhdistyksen kotisivuilla. Kiinnostavaa oli joka tapauksessa analysoida vastaajien vapaata ja luovaa ilmaisutapaa avointen kysymysten vastauksissa, mutta myös jonkin verran hyödyntää osittain kvantifioitua aineistoa (ks. Tuomi \& Sarajärvi 2013). Tällaisen kokemuksiin perustuvan lomaketutkimuksen analyysi oli kuitenkin paras toteuttaa pääasiassa sisällönanalyysiä hyödyntäen ja aineistolähtöisesti, jotta ko. ilmiön olemuksesta työelämässä ja johtamisessa voitiin saada eksaktia perustietoa (ks. Eskola \& Suoranta 2003). Toki tutkijat olivat perehtyneet lähtökohtaisesti teemaan, koska teoreettista tutkimusta erityisherkkyydestä oli olemassa, joskaan ei tässä suomalaisessa kontekstissa.

Kyselyn vastausaikaa olisi voinut jatkaa pidempään, jolloin aineiston määrä olisi todennäköisesti hieman kasvanut. Saatua vastausprosenttia voidaan joka tapauksessa pitää melko relevanttina vastaaviin tämän ajan muihin kyselytutkimuk- 
siin verrattuna. Luotettavuus ja eettisyys ovat aina huomioitavia asioita tutkimuksen tekemisessä, ja tämän tutkimuksen luotettavuutta sekä uskottavuutta vahvisti, että kysely tehtiin kohdennetusti erityisherkkien yhdistyksen jäsenille, jotka itse tunnistavat teeman ja heillä on taustanaan vahva kokemuksellisuus. Tutkimuksen tulosten käsittelyssä tavoiteltiinkin mahdollisimman selkeästi totuudellisuutta ja mahdollista sovellettavuutta muihin vastaaviin tutkimuskohteisiin. (ks. Eskola \& Suoranta 2003; Tuomi \& Sarajärvi 2013.) Totuudellisuus perustui aineistosta poimittuihin vastaajien ilmaisuihin, tuloksissa nostettuihin siteerauksiin ja tutkijan rakentamiin tulkintoihin. Eettisyys perustui puolestaan kyselyn vastaajien anonymiteettiin, jota vahvisti se, ettei tutkija saanut vastaajien sähköpostiosoitteita, vaan kysely lähetettiin Suomen Erityisherkkien Yhdistyksen (HSP) kautta.

Jatkoa ajatellen kvantitatiivinen tutkimus voisi kohdentua aihepiiriä käyttäen eri ammattialoille, mutta erityisesti sosiaali- ja terveysalalle sekä koulutusalalle, joilla on persoonallisuudeltaan erityisherkkiä työntekijöitä määrällisesti paljon ainakin tämän tutkimuksen aineiston perusteella. Lisäksi tutkimusta voisi suunnata johtamistehtävissä toimiville henkilöille ja kartoittaa heidän erityisherkkyyttään tai ymmärrystään erityisherkkyydestä. Toki varsinaista herkkyyttä voisi tutkia muutenkin laajempaa populaatiota hyödyntäen, mutta sen tutkimuksen tavoite ja näkökulma olisivat todennäköisesti erilaisia.

Moninaisuuteen kytkeytyvää erityisyyttä ja erilaisuutta tarvitaan, samoin innovoimista ja uuden luomista, siksi yksilön erityisherkkyys tulisi huomioida työelämässä. Erilaisuutta voi

\section{LÄHTEET}

Ajanko, Sari (2019). Moninaisuuden johtaminen - ytimessä johtajan itsetuntemus. Viro: Suomen Liikekirjat.

Akinci Vural, Beril Z. \& Liedtke, Canan (2017). Diversity Management and Corporate Culture: A System-Theoretical Perspective. E-journal of Faculty of Communication, 5(1). Turkey: Gumushane University.

Alasuutari, Pertti (1999). Laadullinen tutkimus. 3. uudistettu painos. Tampere: Osuuskunta Vastapaino. hyödyntää, kun oppii iloitsemaan siitä. Tämä edellyttää tarkempaa erilaisiin ihmistyyppeihin ja toimintatapoihin tutustumista ja niiden tuottaman hyödyn ymmärtämistä. Useat merkit viittaavat siihen, että työelämässä ollaan ohittamassa ekstroversion lakipiste ja kulkemassa kohti introvertinpää aikaa (vrt. Jonkman 2015). Tästä esimerkkinä internetin toimiminen myyntikanavana ja sosiaalisen median toimiminen yhteisönä introverteille. Ei tarvitse korottaa ääntään tulematta näkyviin hiljaisesti. Myös erityisherkkyys kannattaa työelämässä ja johtamisessa nostaa näkyviin enemmän, sillä näissä moninaisuuteen kytkeytyvissä persoonallisuuksissa on paljon tehokkuutta ja potentiaalia, kun se vain oikein oivalletaan (vrt. Aron 2017). Seuraavat kahden vastaajan kommentit toimivat erinomaisen hyvin tämän artikkelin loppusanoina.

"Se että joutuu kokoajan peittelemään, "tsemppaamaan", olemaan erilainen kuin oikeasti on, kuluttaa psyykettä ja on stressaavaa. Lapsesta asti pitäisi huomioida erilaiset luonteet, temperamentit ja antaa hyväksyntää, tukea. Ujous ja herkkyys voivat olla positiivisia voimavaroja." "Erityisherkkyys ei mielestäni näy tarpeeksi työelämässä, tai ainakaan sitä ei osata hyödyntää eikä sen mahdollisuuksista sekä haasteista puhuta tarpeeksi".

Lämmin kiitos kaikille tutkimukseen vastanneille erityisherkille henkilöille ja Suomen Erityisherkät (HSP) ry:n hallitukselle mahdollisuudesta toteuttaa tutkimuskysely yhdistyksen kotisivujen kautta.

Aron, Elaine N. \& Aron, Arthur (1997). SensoryProsessing Sensitivity and Its Relation to Introversion and Emotionality. Journal of Personality and Social Psychology, 3(2), 345-368.

Aron, Elaine N, Aron, Arthur \& Jagiellowicz, Jadzia (2012). Sensory Processing Sensitivity: A Review in the Light of the Evolution of Biological Responsivity. Personality and Social Psychology Review, 16(3), 262-282.

Aron, Elaine N. (2017). The Highly Sensitive Person. How to Thrive When the World Overwhelms You. London: Harpercollins Publishers. 
Colliander, Anna-Liisa, Ruoppila, Isto \& Härkönen, Leena-Kaisa (2009). Yksilöllisyys sallittu. Moninaisuus voimaksi työpaikalla. Jyväskylä: PS-kustannus.

Copee, Neil \& Galloway, Jo (2014). Leadership \& Management in Healthcare. 2nd Edition. London: SAGE Publications Ltd.

Emirbayer, Mustafa \& Mische, Ann (1998). What Is Agency? American Journal of Sociology, 103(4), 962-102.

Eskola, Antti (1985). Persoonallisuustyypeistä elämäntapaan. Persoonallisuuden tutkimuksen metodologisia opetuksia. Juva: WSOY.

Eskola, Ari \& Suoranta, Juha (2003). Johdatus laadulliseen tutkimukseen. Tampere: Osuuskunta Vastapaino.

Fuchs, Stephan (2001). Beyond Agency. Sociological Theory, 19(1), 24-40.

Gardenswartz, Lee \& Rowe, Anita (1998). Managing Diversity. A Complete Desk Reference and Planning Guide. Revised edition. New York: McGraw-Hill.

Gerlach, Martin, Farb, Benson, Revelle, William \& Nunes Amaral, Luis A. (2018). A robust datadriven approach identifies four personality types across four large data sets. Nature Human Behaviour, 2, 735-742.

Greven, Corina U., Lionetti, Francesca, Booth, Charlotte, Aron, Elaine, Foxe, Elaine, N., Schendan, Haline, E., Pluess, Michael, Bruining, Hilgo, Acevedo, Bianca, Bijttebier, Patricia \& Homberg, Judith (2019). Sensory Processing Sensitivity in the context of Environmental Sensitivity: Acritical review and development of research agenda. Neuroscience and Biobehavioral Reviews, 98, 287-305.

Helms Mills, Jean, Dye, Kelly \& Mills, Albert J. (2009). Understanding Organizational Change. London: Routledge.

Hitlin, Steven \& Glen H. Elder Jr. (2007). Agency: An Empirical Model of an Abstract Concept. Advances in Life Course Research, 11, 33-67.

Hofstede, Geert. \& Hofstede, Gert Jan (2005). Cultures and Organizations. Software of the Mind. USA: McGraw Hill.

Honkavaara, Sylvi-Sanni (1958). A Critical Reevaluation of the Color and Form Reaction. Journal of Psychology, 45, 25-36.

Isotalus, Pekka \& Rajalahti, Hanna (2017). Vuorovaikutus johtajan työssä. Helsinki: Alma Talent.

Jabe, Marjatta (2017). Erilaisten ihmisten johtaminen. Helsinki: Kauppakamari.

Jagiellowicz, Jadzia, Aron, Arthur \& Aron, Elaine (2016). Relationship between the Temperament Trait of Sensory Processing Sensitivity and
Emotional Reactivity. Social Behavior and Personality, 44(2), 185-200.

Jamieson, David \& O’Mara, Julie (1991). Managing Workforce 2000: Gaining the Diversity Advantage. San Francisco: Jossey-Bass Publishers.

Jonkman, Linus (2015). Introvertit. Työpaikan hiljainen vallankumous. Jyväskylä: Atena.

Joyce, Paul (2012). Strategic Leadership in the Public Services. London: Routledge.

Järvinen, Kati (2014). Työn mielekkyyden johtaminen. Käytännön opas. Helsinki: Talentum.

Laulainen, Sanna (2010). "Jos mittää et anna nii mittää et saa". Strateginen toimijuus ja organisaatiokansalaisuus vanhustyössä. Väitöskirja. Itä-Suomen yliopisto. Yhteiskuntatieteiden ja kauppatieteiden tiedekunta. Kuopio: Kopiojyvä.

Keltikangas-Järvinen, Liisa (2019). Ujot introvertit. Helsinki: WSOY.

Kotiranta, Tuija \& Virkki, Tuija (2011). Toimijuus ja sosiaalisen toiminnan teoria. Teoksessa Tuija Kotiranta, Petteri Niemi \& Raili Haaki (toim.), Sosiaalisen toiminnan teoria (s. 113-132). Helsinki: Gaudeamus University Press.

Löhken, Sylvia (2016). Introt ja ekstrot vastaparista voimapariksi. Helsinki: Viisas Elämä Oy.

Manninen, Sylvi-Sanni (1999). Outolintu, erilainen. Tutkimusraportti yliherkästä väri-ihmisestä muotojen yhteiskunnassa. Jyväskylä: Atena kustannus.

Mannix, Elizabeth \& Neale, Margaret A. (2005). What Differences Make a Difference? The Promise and Reality of Diverse Teams in Organizations. American Psychological Society, 6(2), 31-55.

Manz, C. Charles (1992). Self-leading Work Teams: Moving beyond Self-management Myths. Human Relations, 45(11), 1119-1140.

Martela, Frank \& Jarenko, Karoliina (2017). "Itseohjautuvuus tulee, oletko valmis?" Teoksessa Frank Martela \& Karoliina Jarenko (toim.), Itseohjautuvuus. Miten organisoitua tulevaisuudessa? (s. 9-32). Helsinki: Alma Talent.

McKee, Ann (2015). Learning, Talent \& Leadership Development: Evolution or Revolution? Talent Development, 69(3), 38-43.

Ollila, Seija (2006). Osaamisen strategisen johtamisen hallinta sosiaali- ja terveysalan julkisissa ja yksityisissä palveluorganisaatioissa. Johtamisosaamisen ulottuvuudet työnohjauksellisena näkökulmana. Acta Wasaensia 156. Sosiaali- ja terveyshallinto 1 . Vaasan yliopisto.

Ollila, Seija (2008). Strategic Support for Managers by Management Supervision. Leadership in Health Services, 21(1), 16-27.

Ollila, Seija (2013). Productivity in Public Welfare 
Services is Changing: The Standpoint of Strategic Competence-Based Management. Social Work in Public Health, 28, 566-574.

Ollila, Seija \& Kujala, Anne (2018). Narsistinen johtajuus sosiaali- ja terveysalalla. Hallinnon Tutkimus 37(3), 187-200.

Perttula, Juha (2012). "Itsensä johtaminen". Teoksessa Juha Perttula \& Antti Syväjärvi (toim.), Johtamisen psykologia. Ihmisten johtaminen muuttuvassa työelämässä (s. 125-156). Jyväskylä: PS-kustannus.

Santos, Myrna J. (2015). "Introdaction". Teoksessa Myrna J. Santos (toim.), An Introvert in an Extrovert World: Essays on the Quiet Ones (s. 1-5). Englanti: Cambridge Scholars Publishing.

Satri, Janna (2019). Herkkyys voimavaraksi. Tietoa erityisherkille ja heitä kohtaaville. Helsinki: Viisas Elämä Oy.

Schmid Mast, Marianne, Jonas, Klaus \& Hall, Judith. A. (2009). Give a Person Power and He or She Will Show Interpersonal Sensitivity: The Phenomenon and Its Why and When. Journal of Personality and Social Psychology, 97(5), 835850.

Smolewska, Kathy A., McCabe, Scott B. \& Woody, Erik Z. (2006). A psychometric evaluation of the Highly Sensitive Person Scale: The Components of Sensory-processing Sensitivity and Their Relation to the BIS/BAS and "Big Five". Personality and Individual Differences, 40, 1269-1279.

Sobocko, Karin \& Zelenski, John M. (2015). Trait Sensory-processing sensitivity and Subjective Well-being: Distinctive Associations for Different Aspects of Sensitivity. Personality and Individual Differences, 83, 44-49.

Stefan Lindsay, Julie (2017). The Highly Sensitive Teacher: Sensory-processing Sensitivity, Burnout, and Self-Efficacy in Urban Public School Teachers. Thesis/dissertation, University of California.

Tavares, Susana, M. (2016). How Does Creativity at Work Influence Employee's Positive Affect at Work? European Journal of Work and Organizational Psychology, 25(4), 525-539.

Tuomi, Jouni \& Sarajärvi, Anneli (2013). Laadullinen tutkimus ja sisällönanalyysi. Helsinki: Tammi.

Von Bergen, C.W., Soper, Barlow \& Foster, Teresa (2002). Unintended Negative Effects of Diversity Management. Public Personnel Management, 31(2), 239-251.

Wiskari, Juha (2009). Totuuden hetki. Esimiestyö palveluympäristössä. Helsinki: Talentum.

Zigurs, Ilze (2003). Leadership in Virtual Teams: Oxymoron or Opportunity? Organizational Dynamics 31(4), 339-351. 